\title{
To What Extent is Ezekiel the Source of Resurrection of the Dead in 4Q385 Pseudo-Ezekiel and Targum Ezekiel?
}

\author{
AnNeTte Evans (UFS)
}

\begin{abstract}
This article is a response to Daniel Block's recent statement that Ezekiel offers hope to the people that "there is life after death and there is hope beyond the grave," but some scholars have objected to what has been called Christian supersessionalism. The research question is a) whether concepts of resurrection of the dead can have had their source in specific passages in the book of Ezekiel, and if so, b) whether the concept in Ezekiel applies to the "house of Israel" as a group, or to righteous individuals. Ezekiel marks the transition from pre-exilic Israelite religion to post-exilic Judaism and it has been suggested that he laid the foundation for the symbolic universe of apocalypticism. The eschatological element of judgment after death has now been seen to be an essential part of Jewish apocalypticism. The essence of the research question is: to what extent can Ezekiel be seen to have born such eschatological seeds? For various reasons, it is not possible to construct a linear progression of beliefs about the afterlife in Hebrew texts. Therefore the methodological approach was to examine relevant sections of two later extra-Biblical Jewish texts which are both clearly based on Ezekiel and which are both to some extent concerned with resurrection after death. Consequently relevant passages in $4 Q 385$ Pseudo-Ezekiel and Targum Ezekiel have been compared to Ezekiel MT to yield some indication of the actual connections in this regard.
\end{abstract}

Key words: Ezekiel, Qumran, supersessionalism, life after death, Jewish apocalypticism

\section{A INTRODUCTION}

The glory has departed from Israel, for the ark of God has been captured (1 Sam 4:21-22).

Some centuries after the ark of God is captured, the Temple itself is destroyed; the disaster is final. With his book, Ezekiel responds to "the indispensable need to establish a surrogate for the demolished Sanctuary." ${ }^{1}$ However, Daniel

* Article submitted: 24/11/2014; accepted: 10/02/2015. To cite: Annette Evans, “To What Extent is Ezekiel the Source of Resurrection of the Dead in 4Q385 PseudoEzekiel and Targum Ezekiel," OTE 28/1(2015): 70-85, DOI: http:// dx.doi.org/10 .17159/2312-3621/2015/v28n1a6 
Block's recent statement that Ezekiel offers hope to the people that "there is life after death and there is hope beyond the grave" must be qualified. ${ }^{2}$ Some scholars have reacted against Christian supersessionalism. ${ }^{3}$ The prophetic role played by Ezekiel in his vision of the valley of dry bones in ch. 37 is contentious because he lived at a time when death and an afterlife was not part of the Israelite tradition. It was a long time before Judaism (as opposed to Israelite religion) began to explore the concept of resurrection based on the judgments of a person's or nation's conduct. ${ }^{4}$ This article examines whether there is any content in the text of Ezekiel that actually conveys belief in individual resurrection after death.

\section{B METHODOLOGY}

It is impossible to construct a linear progression of beliefs about the afterlife in Hebrew texts because, firstly, there are too few literary voices remaining from each time period. ${ }^{5}$ Secondly, the few records of the eschatological beliefs of "the teachers who flourished in the centuries before the destruction of the [second] Temple . . have been filtered through the later rabbinic academies." 6 Thirdly, by the late Hellenistic period Jewish identity was very diverse. ${ }^{7}$ To

1 Samson H. Levey, The Targum of Ezekiel: Translated, with a Critical Introduction, Apparatus and Notes (ArBib 13; Minnesota: The Liturgical Press, 1987), 3.

2 Daniel I. Block, By the River Chebar: Historical, Literary, and Theological Studies in the Book of Ezekiel (Eugene, Oreg.: Wipf \& Stock, 2013), 198.

3 On the reaction to Christian supersessionalism by Jon D. Levenson see Walter Breuggemann, The Theology of the Old Testament: Testimony, Dispute, Advocacy (Minneapolis: Fortress Press, 1997), 95. Also see John J. Collins, "The Afterlife in Apocalyptic Literature," in Death, Life-After-Death, Resurrection \& The World-toCome in the Judaisms of Antiquity (vol. 4 of Judaism in Late Antiquity; ed. Alan J. Avery-Peck and Jacob Neusner; Leiden: Brill, 2000), 119; Bruce M. Metzger and Roland E. Murphy, eds., The New Oxford Annotated Bible containing the Old and New Testaments (New York: Oxford University Press, 1994), 1057.

4 Larry Lincoln, 2014: personal communication.

5 Richard E. Friedman and Shawna D. Overton, "Death and Afterlife: The Biblical Silence," in Death, Life-After-Death, Resurrection \& The World-to-Come in the Judaisms of Antiquity (vol. 4 of Judaism in Late Antiquity; ed. Alan J. Avery-Peck and Jacob Neusner; Leiden: Brill, 2000), 55-56.

6 Christopher Rowland, The Open Heaven: A Study of Apocalyptic in Judaism and Early Christianity (London: SPCK, 1982), 30. For instance the Targum "bears evidence of the redactive hand of R. Johanan b. Zakkai at Yavneh." See Levey, Targum, 2 .

Sara Raup Johnson, Historical Fictions and Hellenistic Jewish Identity: Third Maccabees in its Cultural Context (Berkeley: University of California Press, 2004), 123, 124 notes for instance that there was a group, as seen in the book of Daniel, which looked forward to "the inevitable coming of God's Kingdom to sweep the world away and replace it with a better one," but on the other hand there were those 
overcome these obstacles the methodological approach in this article was to examine, and compare to Ezekiel MT, relevant sections of two extra-Biblical Jewish texts which are both clearly based on Ezekiel and which are both concerned with resurrection after death: 4Q583 Pseudo-Ezekiel and Targum Ezekiel. This article explores whether the allusions to resurrection in these later texts can be directly related to specific passages in Ezekiel, or whether this element arose later from other connections. The general scholarly opinion that the book of Ezekiel was written by the prophet himself during his exile in Babylon after the destruction of the Temple in c. 600 B.C.E. is accepted as valid. ${ }^{8}$ Initially, in order to achieve the broadest and most representative analysis of the main themes and their sequence in Ezekiel, and to make sense of the text as an independent entity within the ANE cultural context, the holistic approach described by Cook was followed. ${ }^{9}$

One of the effects of the exile was that the Israelites were forced into cultural contact with a much wider ANE context. The cultural changes that took place between the time of Ezekiel and the writing of Pseudo-Ezekiel and Targum Ezekiel and its later redaction are taken into account, and so are pre-existent ideas in the wider ANE culture to which Ezekiel was exposed during his exile. For instance, indications of the concept of resurrection are attested in Persian religion long before it appears in Judaism. ${ }^{10}$ Bernard Lang recognises that Ezekiel must have been "creatively receptive to foreign ideas rather than bound by Israelite tradition." 11 This observation conforms to the psychological theory of apperceptive mass, which is defined as "a group of present ideas, influential in determining what new ideas shall gain admission to consciousness and in what way new objects shall be perceived."12 Thus it is envisaged that Ezekiel creatively combined the potential of his own apperceptive mass with the ideas with which his new circumstances brought him into contact, thereby achieving innovation. For instance several features of the "dry bones" vision in Ezek 37 could be understood from Zoroastrian beliefs about resurrection because they were present in the area to which Ezekiel was exiled. ${ }^{13}$

who "lived under or looked to Hasmonean rule, those who thrived under foreign rule, and those who sought a niche in the wider Hellenistic world."

8 All English translations of the HB are from the NRSV unless otherwise stated.

9 Johann Cook, The Septuagint of Proverbs - Jewish and/or Hellenistic Proverbs? Concerning the Hellenistic Colouring of LXX Proverbs (Leiden: E. J. Brill, 1997), 41.

10 Isaiah 26:19, dated to the sixth century B.C.E., is a debatable exception.

11 Cf. Paul Tillich, The Shaking of the Foundations (Harmondsworth: Penguin Books, 1963), 116: "The creative man, in all realms of life, is like a child, who dares to inquire beyond the limits of conventional answers."

12 Raymond J. Corsini, The Dictionary of Psychology (London: Brunner-Routledge, 2002), 61.

13 John J. Collins, The Dead Sea Scrolls: A Biography (Princeton: Princeton University Press, 2013), 155 observes that scholars have long suspected that the "whole sys- 
Ezekiel marks the transition from pre-exililic Israelite religion to postexilic Judaism and it has been suggested that he laid the foundation for the symbolic universe of apocalypticism. ${ }^{14}$ The eschatological element of judgment after death has now been seen to be an essential part of Jewish apocalypticism. ${ }^{15}$ The essence of the research question is: to what extent can Ezekiel be seen to have born such eschatological seeds?

\section{THE THEMES AND THEIR SEQUENCE IN EZEKIEL}

(i) In ch. 1 Ezekiel describes how the heavens were opened, and he saw "visions of God" מראות אלהים on a mobile throne in heaven. ${ }^{16} \mathrm{~A}$ voice informs Ezekiel that he is to announce to the people of Israel that Israel is a rebellious nation. Punishment is to be executed as an instruction to all nations.

tem of thought known as apocalyptic," which "appears as a novelty in Judaism in the second century BCE," might be influenced by Zoroastrianism The Zoroastrian religion appears to have originated in about the middle of the second millennium B.C.E.. Collins notes that a difficulty of delineation arises because although many of the most important sources for Zorastrianism clearly preserve old traditions the written records are relatively late (sixth to ninth centuries C.E.). Orthodox Judaism argues against the possibility of Ezekiel having been influenced by Zoroastrianism on the basis of Num 19:16 ("And whosoever toucheth . . . a bone of a man . . . shall be unclean seven days"), but Bernard Lang, "Street Theatre, Raising the Dead, and the Zoroastrian Connection in Ezekiel's Prophecy," in Ezekiel and his Book: Textual and Literary Criticism and their Interrelation (ed. Johan Lust; Leeuven: Uitgeverij Peeters, 1986), 297-316, specifically 315-316, argues cogently against such objections.

14 Metzger and Murphy, New Oxford, 1057.

15 John J. Collins, "The Genre Apocalypse Reconsidered" (paper presented at the international meeting of the SBL, Vienna, 7 July 2014.

16 For previous research on the complexities of the Merkevah throne please see Annette H. M. Evans, "The Development of Jewish Ideas of Angels: Egyptian and Hellenistic Connections c.600 BCE to c. 200 CE." (D. Phil diss., University of Stellenbosch, 2007); Annette H. M. Evans, "Jewish Angelology and the Absence of Ezekiel 1:14 and 10:14 in the Old Greek Version of the Septuagint," OTE 20/3 (2007): 653668; Annette H. M. Evans, "Aspects of Ezekiel 1:14 in Angelological Texts Found at Qumran," JSem 17/2 (2008): 443-464; Annette H. M. Evans, "Comparison of the Structure of LXX and MT Versions of Ezekiel 1:27 and 8:2." APB 20 (2009): 377-388; Annette H. M. Evans "The Origins of Jewish Beliefs in Angels," Scriptura 101/2 (2009): 198-205; Annette H. M. Evans; “"As for the Wheels, it was Cried unto Them in my Hearing, O Wheel': Angelological and Divinatory Connections in Ezekiel 10:13," JSem 21/2 (2012): 222-236; Annette H. M. Evans, "Magical nehushtan and Mystical hashmal: Two Sides of the Same Ancient Near Eastern Coin?" JSem 22/1 (2013): 163-176; Annette H. M. Evans, "חשמל: Is It Amber or Metal?" JSem 23/1 (2014): 135-147. 
(ii) God's Sanctuary had been defiled, God's anger demands judgment. The site of punishment of the house of Israel, Jerusalem, is in the midst of the fire, in the midst of the nations, in their sight. In ch. 5:5 the Lord God announces: "This is Jerusalem: I have set it in the midst of the nations and countries [that are] round about her."17 In ch. 6 Ezekiel is instructed to prophesy judgment not only against Jerusalem, but also against the mountains because of their high places which are associated with idols. In the same breath, as it were, condemnation is relieved by the promise in 6:8: "yet will I have a remnant." ${ }^{18}$ God's concern and disappointment with Israel is passionately expressed in v. 6:9.

(iii) In ch. 7 God's appalling judgment on the "land of Israel" is all the more stunning; the end of the land will come. Because of God's anger the land of Israel will be recompensed according to their abominations: "An end is come: the end is come, it watcheth for thee; behold, it is come" (v. 6 $\mathrm{KJV})$. It is reiterated that God's righteous judgment at the "end" (7:6) is to take place "in the midst of the nations ... in the sight of all that pass by." The justification for judgment is hammered home in ch. 8: Ezekiel specifies the year, month and day when he again sees the vision of God in the northern entrance of the gate of the altar, but through a hole in the wall Ezekiel is shown "abominations."

(iv) In ch. 9 the highly significant theme of the remnant mentioned in $6: 8$ is re-iterated: ". . . the men that sigh and cry for all the abomination" will be spared. Ezekiel then sees six men. One of the six, who is clothed in linen, is instructed to "put a mark upon the foreheads of the men that sigh and cry for all the abomination." The other five men go in and smite all the rest of the people. Here the righteous - those that "sigh and cry for all the abomination" - are to be rewarded, but notably, in contrast to the specification in ch. 8 of when Ezekiel sees the vision, it is not clear when and where "the end" will take place, yet it has been specified (Ezek 7:6) that the punishment will take place in the midst of the nations, in their sight.

(v) In ch. 10 the "glory of the Lord" moves to the threshold of the Temple, and the man dressed in linen is instructed to take burning coals from among the cherubim and scatter fire over Jerusalem. The "glory of the Lord" כבוד יהוה then moves toward the eastern exit of the house of the Lord בית יהוד, but now it is the "glory of the God of Israel."

17 Structurally, this verse may be an inclusion in that it forms the (approximate) centre between the occurrences of the mysterious word חשממל in ch. 1 and the only other occurrence of the word in ch. 8:2. See Evans, "Comparison," 383.

18 Intertextually, there is poignancy here, as it seems to allude to Ps $125: 2$, "As the mountains are round about Jerusalem, so the Lord [is] round about his people from henceforth even forever." 
(vi) That God will gather the remnant is again repeated in ch. 11, but with more detail: God will put a new spirit within them, give them the land of Israel, and God will be their God אלוהים. Again, it is not clear when this will take place.

The agenda of the entire book is stated in these first eleven chapters: God is "broken" by the rebelliousness of the house of Israel. His only comfort is by venting his jealous anger in retribution on the entire house of Israel, but those men who are also upset by the abominations (by implication, those who are righteous) will be spared ("touch no-one who has the mark"). The essence is stated in ch. 11: God says that he will gather the remnant of Israel, put a new spirit within them, and give them the land of Israel: "and they shall be my people, and I will be their God." This pattern of succession of themes is basically repeated in more detail throughout the rest of the book. Chapters 12 to 34 contain prophecies against the surrounding nations, but the Lord God again promises restoration and forgiveness for "Jerusalem" at the end of ch. 16. The promise that the righteous (of "the house of Israel") will live is reiterated in chs. 18, 20 , and 34, but always framed in ambiguous terms in such a way that it is never certain whether it is righteous individuals or "the house of Israel" as a whole, will live. From ch. 36 onwards the hope for Israel is powerfully expressed, especially in ch. 37 containing the "dry bones prophecy." Verse 11 is very specific: "these bones are the whole house of Israel." From ch. 40 onwards the measurements and description of the Temple area "in the visions of God" in the "land of Israel," a structure "like a city to the south" are described. The measurements are specific but the diachronic aspects are indefinable and at very least, ambiguous. Chapter 48 ends the book with the conclusion that the name of the Temple shall be "the Lord is there." The statement "They shall know that I am God" is a constant refrain throughout the book of Ezekiel. These themes and their sequence are considered where relevant in the following two texts.

\section{4Q385 PSEUDO-EZEKIEL}

The date of Pseudo-Ezekiel (hereafter $P s-E z$ ) is assumed to be during the reign of Antiochus IV Epiphanes, i.e. 175-164 B.C.E.. It deals with the shortening of times (4Q385 5), resurrection (4Q385 2, 12), and the eschatological Temple (4Q391), and is the earliest witness to the exegesis of the "dry bones" prophecy of Ezek 37:1-14 as specifically presenting the future reward for the righteous in the form of resurrection. ${ }^{19}$ Although biblical in style, certain forms such as ("a joint") and ("who redeems") betray that Pseudo-Ezekiel has a postbiblical background, but no specifically sectarian terminology occurs in the extant fragments. Belief in resurrection was a widespread theme in Jewish and

19 Devorah Dimant, Pseudo-Prophetic Texts (vol. 4 of Qumran Cave 4, XXI: Parabiblical Texts; DJD 30; Oxford: Clarendon Press, 2001), 9, 12-13, 16, 36. 
Christian texts from the second century B.C.E. onwards, but no explicit formulation of such a belief can be traced in any of the extant sectarian writings.

4Q385 Pseudo-Ezekiel Frg. 2 lines 1-10

[כי אני יהוה] הגואל עםי לתת להם הברית

[for I am the Lord] who redeems my people, giving unto them the covenant. Vacat

]ואמרה יהוה] ראיתי רבים מישראל אשר אהבו את שמך וילכו

[And I said: "O Lord!] I have seen many (men) from Israel who have loved your Name and have walked

\section{בדרכי[ לבך וא[לה מתי יהיו והיככה ישתלמו חסדם ויאמר יהוח}

in the ways of [your heart. And th] ese things when will they come to be and how will they be recompensed for their piety?" And the Lord said

vacat

אלי אני אראה] [את בני ישראל וידעו כי אני יהוה

To me: "I will make (it) manifest[ ]to the children of Israel and they shall know that I am the Lord." Vacat

ויאמר [כן אדם הנבה על העצמות ואמרתויק בו עצם אל עצםו ופרק

[And He said:] "Son of man, prophesy over the bones and speak and let them be j[oi]ned bone to its bone and joint

[אל פרקו ויה]י כן ויאמר שנית הנבא ויעלו עליהם גדים ויקרמו עור

20 The text and translation is from Dimant, Pseudo-Prophetic, 23-24. She notes that some parts are paralleled in 4Q386 1 and 4Q388 7. 
Evans, "To what extent is Ezekiel," OTE 28/1 (2015): 70-85

[to its joint." And it wa]s so. And He said a second time: "Prophesy and let arteries come upon them and let skin cover them

[מלמעלה ויהיכך] ויאמר שוב אנוא על ארבע רוחות השמים ויפחו רוח

[from above." And it was so.] And he said: "Prophesy once again over the four winds of heaven and let them blow breath

\section{[בהרוגי ויהי כן] וי[ח]יו עם רב אנשים ויברכו את יהוה צבאות אש[ר]}

[into the slain." And it was so,] and a large crowd of people came [to li]fe and blessed the Lord Sebaoth who[o]

\section{[חים vacat}

[had given them life. vacat and] I said: "O Lord! When shall these things come to be/" And the Lord said to m[e: "Until ]

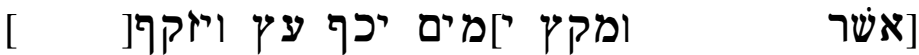

[ after da]ys a tree shall bend and shall stand erect" [ ]

The initial description of the valley filled with dry bones in the MT is omitted. Instead, the bones are introduced as known, which reflects the exegetical character of $P s-E z$. Lines 2-4 mention the righteous of Israel, and the highly relevant question about the time and manner of the reward for them is ascribed to Ezekiel, whereas it is never voiced in the biblical text. The description of the revival of the bones omits "flesh," using "joint" and "artery" instead. Thus, instead of the two-stage process of the original prophecy - reconstituting the body and reviving it by blowing breath into it, $P s-E z$ has a three-stage process: 1) assembling the bones and joints; 2) covering them with arteries and skin; 3) blowing breath into the assemblage. ${ }^{21}$ The restored section in line 8: "to life" reads differently in the parallel fragment 4Q386, 1 i line 9: "stood on their feet." Resurrection here seems to be understood in concrete terms, as a real

21 Dimant, Pseudo-Prophetic, 24, 33. I would suggest that "veins," or simply "blood-vessels" would be a more accurate translation of what would have been meant by גדים. 
event intended for the future. ${ }^{22}$ It must be noted that both these versions, although in agreement with the MT, are restorations.

The Qumran community described a transcendent, spiritual realm in symbolic and mythological terms as a celestial temple in which angel priests offered sacrifices to God in the form of praise and blessing. ${ }^{23}$ Alexander claims that there is no doubt that the Qumran community interpreted Ezekiel's description of the new temple as metaphorical, not an earthly, three dimensional one, but ton the other hand they did believe that heavenly ascent could be achieved during life on earth. This view is also evident in the Angelic Liturgy 4Q Shir Shabbat. ${ }^{24}$

In 4Q385 6 1-4 the theme of resurrection is followed by a Merkebah vision. Dimant suggests that this sequence is possibly modelled on Ezekiel 43:1-5, which again alludes to the Ezek 1 Merkebah vision, and she thus deduces that $P s-E z$ views the Merkebah vision as forming part of the eschatological sequence because it is presented in the context of the earthly future/visionary temple. ${ }^{25}$ Thus here the surviving passages of $P s-E z$ facilitate coherence in the sequence of thought in MT Ezek 37-43, where the theme of resurrection is followed by the Merkebah vision. In that $P s-E z$ connects the Merkebah throne very directly with resurrection, the implication is that all these scenes should be resigned to the sphere of the final, redemptive era. ${ }^{26}$ The element of judgment is inevitably connected to the Merkebah throne. The importance of this eschatological factor becomes more evident in Targum Ezekiel.

\section{E TARGUM EZEKIEL}

T. Ezekiel is written in Palestinian Aramaic, and was redacted by R. Johanan b. Zakkai at Yavneh. Having been revised and edited in Babylon, it was probably finally redacted by Saadia Gaon in the early part of the 10th Century. ${ }^{27}$ The theology of the Ezekiel Targum is basically Pharisaic-Rabbinic, which per-

22 Dimant, Pseudo-Prophetic, 33-34 (contra Collins). Collins, "Afterlife," 119, understands Ezekiel to be speaking of a resurrection of the House of Israel and prophesying a return to their land. He maintains that this assertion applies to $P s-E z$ as well. See John J. Collins, Daniel: A Commentary (Hermeneia; Minneapolis: Fortress, 1993), 397.

23 Philip Alexander, Mystical Texts (London: T \& T Clark International, 2006), 72, 90.

24 See Evans, "Development," 98.

25 Dimant, Pseudo-Prophetic, 11, 21, 32. OG Papyrus 967 (3rd century C.E.) possibly reflects a Hebrew Vorlage differing from MT.

26 Dimant, Pseudo-Prophetic, 32.

27 The evidence of the Targums of section of Job and fragments of Leviticus found at Qumran indicate that the HB was being translated into Aramaic before the Christian era, but the Targums have been transmitted down to us through Rabbinic Judaism. 
ceives God as "the transcendent deity, whose abode is in the mysterious celestial realms." The resurrection of the dead was a cardinal doctrine of the Pharisaic-Rabbinic Tradition. ${ }^{28}$ The theme of throne mysticism and its concomitants pervades the entire Targum.

Targum Ezekiel has several significant differences from the MT. The following differences related to eschatology/resurrection found in Targum Ezekiel are considered: judgment; a remnant; the righteous will live "in eternal life."

\section{Judgment, but a Remnant}

Ezekiel is being sent to the "children of Israel," a "rebellious nation," to warn them that they and their fathers have transgressed against אדני יהוה, "because you have defiled my sanctuary." In MT Ezek 6:8 Ezekiel is instructed to prophesy "But I will spare some." Targum Ezekiel has "But I will leave a remnant of you among the nations, when some of you are saved from the sword, and when you are scattered among the countries." In MT Ezek 6:9b God's care and disappointment with Israel is passionately expressed: "How I was crushed by their wanton heart that turned away from me, and their wanton eyes that turned after these idols." Here the Targum is quite different: "How I broke (active form, rather than the passive MT) their foolish heart which had deserted My worship, and the sight of their eyes which had strayed after idols." Here in the Targum God is not vulnerable and passive, God is powerful and his vengeance is certain. Another striking difference is that because God's anger requires that the land of Israel is recompensed according to its abominations. MT has: "An end has come: the end has come. It has awakened against you; see, it comes!" (7:6), but here the Targum has "The Kingdom has been revealed." Levey interprets this phrase to mean "the day of Yahweh, the day of retribution." ${ }^{, 29}$ God's appalling judgment and retribution is followed by Ezekiel's specification of the year,

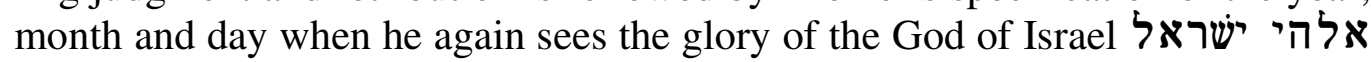
כבוד, now having moved to the Northern entrance gate, but now ominously המקנה "פescribed as "the image of jealousy, which provokes to jealousy" סמל הקנאה.

\section{The Righteous will Live "in Eternal Life"}

In ch. 9 the highly significant element "yet will I have a remnant" previously stated in 6:8 is re-iterated: "The men that sigh and cry for all the abomination"

28 Levey, Targum, vii, 1-2, 5-6, 11, 13. See Josephus, B.J. 2, 8, 14; m.; t. Sanh. 90b92a.

29 Levey, Targum, 33, n. 4. The mythological roots of this apocalyptic metaphor for God as judge are to be seen as far back as Ugarit, where El was the judge, a universal trait of the cultic tradition of the "highest God." See Mark S. Smith, Untold Stories: The Bible and Ugaritic Studies in the Twentieth Century (Peabody, Mass.: Hendrickson, 2001), 49. 
will not be killed. At MT Ezek 20:11 "I gave them my statutes and showed them my ordinances, by whose observance everyone shall live," there is nothing to indicate physical resurrection after death, but here the Targum, very strikingly, specifies that the righteous will live "in eternal life": "And I gave them My statutes, and I made known to them My laws, which if a man observed, he would live by them in eternal life."

\section{Hope for Israel}

At ch. 37:1 Targum Ezekiel adds the adjective "human" to the description of the dry bones, thus expressing agreement with $P s-E z$ 4Q385 Frg. 2 "a large crowd of people came to life." There are several rabbinic explanations for the addition that the bones are human, but Levey (103) finds the most rational explanation in R. Judah b. Hai, b. Sanh. 92b. "In truth it is an allegory," "meaning that it symbolically represents the restoration of the Jews as a people and as a national entity possessing its land once again.",30

\section{F DISCUSSION}

At ch. 20.11 the Targum, very strikingly, specifies that the righteous, namely those who have observed God's statues and laws will live "in eternal life." The later reinforcement at Ezek 37:1 that the bones that "came to life" are "human" seems to imply a perceived difference between humans and animals in terms of the potential for resurrection to eternal life.

As far as the ambiguity in the MT of the time-frame goes, there is a telltale change from third to second person in 4Q385 $P s-E z$ frg. 3 lines 5-6 which indicates a shift in the text from the time of Ezekiel to the time of the author's community. ${ }^{31}$ Thus the text functions on two levels; the people who "rise up" in the fragment are those of Israel at the time of Ezekiel; the "you" at the end of the fragment are the contemporaries of the author, who will be raised from their graves. In $P s-E z$ frg. 2 resurrection seems to be understood in concrete terms, as a real event intended for the future. ${ }^{32}$ In contradiction to most modern critics who view the dry bones vision as a figurative or symbolic prophesy of the future national restoration of Israel, Daniel Block argues that the dry bones passage in the MT reflects an actual belief in resurrection known to the prophet and

30 Levey, Targum, 103 notes that Pirqe R. El, chs. 33, 34 gives a full treatment of ch. 37 and of the Jewish doctrine of the resurrection and of this chapter.

31 Benjamin Wright, "Talking with God and Losing his Head: Extrabiblical Traditions about the Prophet Ezekiel," in Biblical Figures outside the Bible (ed. Michael E. Stone and Theodore A. Bergren; Harrisburg, Pa.: Trinity Press International, 1998), 302-3.

32 Dimant, Pseudo-Prophetic, 33-4 (contra Collins). Collins, “Afterlife," 119, understands Ezekiel to be speaking of a resurrection of the House of Israel and prophesying a return to their land. 
exploited by him. ${ }^{33}$ However, the ambiguity is only much later eliminated in $P s-E z$, in a typical, post-biblical exegetical strategy. In $P s-E z$ the biblical scene of a valley full of bones is omitted; it is assumed that the bones are already familiar to the readers. Dimant notes that this is one of four well known exegetical techniques seen in other contemporary Jewish writings: omission, abbreviation, alteration, and addition." An extra stage in the revival of the bones is added, and the fulfillment formula from Genesis 1 is used: ". . . and it was so." The unspecified future in the MT is replaced with an event belonging to the eschatological era, emphasized by Ezekiel's query: "When will these be?" The interpretive character of $P s-E z$ is also reflected in the decoding the figurative language of the MT, thus transforming the vision from a metaphor about the future national restoration of Israel as a whole into "a vision about the resurrection of individuals as the eschatological recompense reserved for the righteous of Israel alone." In this way resurrection as a reward for individual piety becomes part of a "general concept about individual moral and religious responsibility, explicitly linked to resurrection, in concrete terms."

There is a powerful expression of hope at Ezek 17:22-24 in which YHWH promises to pluck a tender shoot from the very top of the cedar tree and to plant this shoot, clearly a scion of the House of David, "upon a high and steep mountain." 35 On the basis of Ezek 17:24 Dimant suggests that 4Q385 Fr. 2 line 10 "after days a tree shall bend and stand erect" may symbolise death and resurrection. ${ }^{36}$ Ezekiel 17:22-24 seen together with ch. 37, may have influenced the church Fathers to cite the "dry bones prophecy" in ch. 37 as scriptural proof of the validity of belief in the resurrection of the dead, as a prophecy to be fulfilled by Christ in the Second Coming at the end of time (Justin Martyr). ${ }^{37}$ In the entire book of Ezekiel the word ישי (I will save [my flock]"), and then again at 36:29 ("I will save [you from all your uncleannesses.]" It is the house of Israel that is being addressed here) ${ }^{38}$ The third and only other appearance of the word in the entire book is at Ezek 37:23 ("I will save them from all the apostasies into which they have fallen, and will cleanse them. Then they shall be my people, and I will be their God לאלהים"). In the Targum translation the words "deliver" / "redeem" / "redeem" respectively, are used in these places for והושעתת. Eichrodt argues

33 Daniel Block, The Book of Ezekiel: Chapters 25-48 (NICOT; Grand Rapids: Eerdmans, 1988), 367-74.

34 Dimant, Pseudo-Prophetic, 32-34.

35 In this context the mountain can only be Mt. Zion. See Jon D. Levenson, Theology of the Program of Restoration of Ezekiel 40-48 (Ann Arbor, Mich.: Edwards Brothers, Inc., 1976), 7.

36 Dimant, Pseudo-Prophetic, 29.

37 Tertullian sees the dry bones prophecy as reflecting "Ezekiel's doubt concerning the revival of the dead, contrasted with the Christian acceptance of the doctrine as a literal truth, rather than an allegory (Levey, Targum, 103).

38 The whole of ch. 34 is a metaphor of God as shepherd of his flock. 
that it is quite legitimate to call the state of salvation described in Ezek 47 eschatological, because it marks the end of what has hitherto been known as history, and prepares the way for a new event. ${ }^{39}$

Having found traces of belief in resurrection as reward of the righteous individuals connected to the Book of Ezekiel in the two texts discussed, the question now is, to what extent has this exegesis been facilitated by factors such as other cultural beliefs/contexts and later historical developments, and to what extent is an actual physical resurrection implied? Bosman has noted that many indications exist of the creativeness of prophetic innovation that played a crucial role in the hermeneutical process of what has been referred to as "inner biblical exegesis." 40 The technique of linking two biblical verses was an exegetical method widely used in Jewish literature of the Second Temple period, for instance Dan 12:1-2 and LXX Isa 26:19 are second century B.C.E. witnesses to the exegesis of Isa 26:19 as referring to resurrection.

Targum Ezekiel is exegetically non-Messianic, but Levey notes that messianic activism was regarded by Rome as treason against the emperor Rabbi Johanan had to suppress open Messianic activity in order to protect his followers from the charge of treason, but at the same time he had to keep alive their faith in God and their hope for national restitution and restoration of the sovereignty, all symbolised by the eschatological Temple beyond the reach of the military forces of world empires. Another reason for the non-Messianic stance could be that "Rabbinic experience and perception of reality disclosed that living a righteous life and observing the commandments of the Torah did not guarantee security in this insecure world, nor reward in this life. Hence they projected the reward for righteous conduct to life in the hereafter." 41

Metzger \& Murphy assess the description of the Temple to be "somewhat idealised" and the distribution of land as "completely idealistic."42 Rabbbi Johanan insisted that the earthly Jerusalem is a counterpart of the heavenly Jerusalem - a further attestation to the eschatological, divine nature of the reconstructed city of Jerusalem. ${ }^{43}$ In the Merkebah tradition the restoration of the earthly temple depicted by Ezekiel is, according to the Rabbis, the successful replication in the future, of the celestial abode of God. ${ }^{44}$ The temple is not a construction in space, so there can be no specification of time. Physics has

39 Walther Eichrodt, Theology of the Old Testament (vol. 2; London: SCM Press Ltd, 1967), 33; Walther Eichrodt, Ezekiel: A Commentary (London: SCM Press, 1986), 585.

40 Hendrik Bosman, "From 'Divination' to 'Revelation," OTE 27/2 (2014): 377394, specifically 391 .

41 Levey, Targum, 6, 57.

42 Metzger and Murphy, New Oxford, 1111, 1119.

43 Levey, Targum, 3-6.

44 Levey, Targum, 36, 117 n. 6. 
made it clear that time and space cannot be separated, they are intrinsically linked. In this sense the process of restoration in Ezekiel is not on earth, nor within a time frame that is humanly conceivable.

Jon Levenson notes that the mountain to which Ezekiel is transported is a symbol of "divine promise of assurance of things humanly impossible and yet hoped for" and that it is also conceived of in the tones of Sinai - "man's striving within the arena of human events to realize the will of God," suggesting "not security, but the dread of judgment." He suggests that the Temple must be seen, in part, in the light of mythic concepts of a cosmic mountain. The cosmic significance of the Temple is due to the presence of God within, rather than as a place of worship. ${ }^{45}$ Levenson observes that the program of restoration of Ezek 40-48 manifests tension between myth and history - two and a half millennia after the composition of the program of restoration of Ezek 40-48, the inviolability of Zion "still stands as a . . . beacon to all who . . . continue to hope ... in the expectation of standing on that 'very high mountain' (40:2) and catching a glimpse of the city whose name is "The Lord is there" (Ezek $48: 35){ }^{46}$

\section{G CONCLUSION}

In terms of the psychological impact of the Merkebah concept of God in heaven on a mobile throne, Ezekiel's response to the fall of Jerusalem was effective right up to the time of Rabban Johanan b. Zakkai when it had become clear that nationalistic eschatology had failed. ${ }^{47}$ The few but crucial differences between the MT and the two extra-biblical texts indicate that there had been a paradigm shift sometime between the writing of Ezekiel and the later two texts. The time-line of judgment and its consequence in terms of punishment or resurrection of the righteous is always ambiguously stated in Ezekiel MT. The apocalyptic eschatology with its concept of judgment and resurrection of the righteous individual after death which is evident in $P s E z$ and the Targum only became evident several centuries after the writing of the book of Ezekiel. Ps-Ez is the earliest witness to the interpretation of Ezek 37:1-14 as expressing the concept of resurrection in concrete terms as a reward for individual piety. ${ }^{48}$ In contradiction to the possible physical restoration of the earthly Temple which some saw as depicted by Ezekiel, the Targum avoids the anthropomorphism in the description of the Merkebah throne in Ezek 43, and makes subtle intima-

\footnotetext{
45 Levenson, Program of Restoration, 7-8, 10, 161.

46 Levenson, Program of Restoration, 163.

47 Rowland, Open Heaven, 32-4, 37. Dimant, Pseudo-Prophetic, 36, points out that in the light of evidence of earlier witnesses to the belief in resurrection, for instance 1 Enoch 1-36, "the long-established view that the belief in resurrection was incorporated into Judaism during the second century B.C.E. for the purpose of encouraging Jewish martyrs under the persecutions of Antiochus IV, is no longer tenable.

48 Dimant, Pseudo-Prophetic, 36.
} 
tions that the successful replication in the future of the celestial abode of God is meant in a metaphorical sense. Both $P s-E z$ and the Targum portray the connection of the Merkebah throne with judgment and eschatological resurrection; these two texts could only have gained clarity in this regard via later developments. This paradigm shift may well have been potentially under the surface of the Ezekiel text, but to interpret MT Ezekiel as expressing a hope or belief in actual physical resurrection would be a travesty of the wide-ranging and openended fruitfulness of the spirit in which the book of Ezekiel was written.

\section{BIBLIOGRAPHY}

Alexander, Philip. Mystical Texts. London: T \& T Clark International, 2006.

Avery-Peck, Alan J., and Jacob Neusner, eds. Death, Life-After-Death, Resurrection \& the World-to-Come in the Judaisms of Antiquity. Volume 4 of Judaism in Late Antiquity. Leiden: Brill, 2000.

Block, Daniel I. The Book of Ezekiel: Chapters 25-48. New International Commentary on the New Testament. Grand Rapids: Eerdmans, 1988. . By the River Chebar: Historical, Literary, and Theological Studies in the Book of Ezekiel. Eugene, Oreg.: Wipf \& Stock, 2013.

Bosman, Hendrik. "From 'Divination' to 'Revelation."' Old Testament Essays 27/2 (2014): 377-394.

Brueggemann, Walter. The Theology of the Old Testament: Testimony, Dispute, Advocacy. Minneapolis: Fortress Press, 1997.

Collins, John J. Daniel: A Commentary on the Book of Daniel. Hermeneia. Minneapolis: Fortress Press, 1993.

. "The Afterlife in Apocalyptic Literature." Pages 119-140 in Death, LifeAfter-Death, Resurrection \& the World-to-Come in the Judaisms of Antiquity. Volume 4 of Judaism in Late Antiquity. Edited by Alan J. Avery-Peck and Jacob Neusner. Leiden: Brill, 2000.

.The Dead Sea Scrolls: A Biography. Princeton: Princeton University Press, 2013.

Cook, Johann. The Septuagint of Proverbs - Jewish and/or Hellenistic Proverbs? Concerning the Hellenistic Colouring of LXX Proverbs. Leiden: E. J. Brill, 1997.

Corsini, Raymond J. The Dictionary of Psychology. London: Brunner-Routledge, 2002.

Dimant, Devorah. Pseudo-Prophetic Texts. Volume 4 of Qumran Cave 4, XXI:

Parabiblical Texts. Discoveries in the Judaean Desert 30. Oxford: Clarendon Press, 2001.

Eichrodt, Walther. Theology of the Old Testament. Volume 2. London: SCM Press Ltd, 1967. . Ezekiel: A Commentary. London: SCM Press, 1986.

Evans, Annette H. M. "The Development of Jewish Ideas of Angels: Egyptian and Hellenistic Connections c.600 BCE to c. 200 CE." D. Phil diss., University of Stellenbosch, 2007.

. "Jewish Angelology and the Absence of Ezekiel 1:14 and 10:14 in the Old Greek Version of the Septuagint." Old Testament Essays 20/3 (2007): 653-668. 
. "Aspects of Ezekiel 1:14 in Angelological Texts Found at Qumran."

Journal for Semitics 17/2 (2008): 443-464.

. "Comparison of the Structure of LXX and MT Versions of Ezekiel 1:27 and

8:2." Acta Patristica et Byzantium 20 (2009): 377-388.

. "The Origins of Jewish Beliefs in Angels." Scriptura 101/2 (2009): 198-

205.

. "'As for the Wheels, it was Cried unto Them in my Hearing, O Wheel':

Angelological and Divinatory Connections in Ezekiel 10:13." Journal for

Semitics 21/2 (2012): 222-236.

. "Magical nehushtan and Mystical hashmal: Two Sides of the Same Ancient

Near Eastern Coin?” Journal for Semitics 22/1 (2013): 163-176.

. "חשמל: Is It Amber or Metal?" Journal for Semitics 23/1 (2014): 135-147.

Friedman, Richard E. and Shawna D. Overton. "Death and Afterlife: The Biblical

Silence." Pages 35-60 in Death, Life-After-Death, Resurrection \& the World-to-

Come in the Judaisms of Antiquity. Volume 4 of Judaism in Late Antiquity.

Edited by Alan J. Avery-Peck and Jacob Neusner. Leiden: Brill, 2000.

Lang, Bernard. "Street Theatre, Raising the Dead, and the Zoroastrian Connection in Ezekiel's Prophecy." Pages 297-316 in Ezekiel and his Book: Textual and Literary Criticism and their Interrelation. Edited by Johan Lust. Leeuven: Uitgeverij Peeters, 1986.

Levenson, Jon D. Theology of the Program of Restoration of Ezekiel 40-48. Ann Arbor, Mich.: Edwards Brothers, Inc., 1976.

Levey, Samson H. The Targum of Ezekiel: Translated, with a Critical Introduction, Apparatus and Notes. The Aramaic Bible 13. Minnesota: The Liturgical Press, 1987.

Lust, Johan, ed. Ezekiel and his Book: Textual and Literary Criticism and their Interrelation. Leeuven: Uitgeverij Peeters, 1986.

Metzger, Bruce M., and Roland E. Murphy, eds. The New Oxford Annotated Bible Containing the Old and New Testaments. New York: Oxford University Press, 1994.

Raup Johnson, Sara. Historical Fictions and Hellenistic Jewish Identity: Third Maccabees in it's Cultural Context. Berkeley: University of California Press, 2004.

Rowland, Christopher. The Open Heaven: A Study of Apocalyptic in Judaism and Early Christianity. London: SPCK, 1982.

Smith, Mark S. Untold Stories: The Bible and Ugaritic Studies in the Twentieth Century. Peabody, Mass.: Hendrickson, 2001.

Stone, Michael E. and Theodore A. Bergren, eds. Biblical Figures Outside the Bible. Harrisburg, Pa.: Trinity Press International, 1998.

Tillich, Paul. The Shaking of the Foundations. Harmondsworth: Penguin Books, 1963.

Wright, Benjamin. "Talking with God and Losing his Head: Extrabiblical Traditions about the Prophet Ezekiel." Pages 290-315 in Biblical Figures Outside the Bible. Edited by Michael E. Stone and Theodore A. Bergren. Harrisburg, Pa.: Trinity Press International, 1998.

Annette Evans, Research Fellow, University of the Free State Postgraduate School, PO Box 339, Bloemfontein 9300, E-mail: ahmevans@ gmail.com 